\title{
LAND UNITS COMPOSITION OF HOME RANGES AND CHANGING OF WINTER ROOSTS OF LONG-EARED OWL Asio otus
}

\author{
FILIP TULIS ${ }^{1}$, IMRICH JAKAB ${ }^{1}$, ROMAN SLOBODNÍK², MICHAL HUDEC ${ }^{3,1}$
}

${ }^{1}$ Department of Ecology and Environmental Sciences, Constantine the Philosopher University in Nitra, Tr. A. Hlinku 1, 949 74, Nitra, Slovak Republic; e-mail: ftulis@ukf.sk

${ }^{2}$ Raptor Protection of Slovakia, Kuklovská 5, 84104 Bratislava, Slovak Republic

${ }^{3}$ Department of Chemistry, Constantine the Philosopher University in Nitra, Tr. A. Hlinku 1, 949 74, Nitra, Slovak Republic

\begin{abstract}
Tulis F., Jakab I., Slobodník R., Hudec M.: Land units composition of home ranges and changing of winter roosts of long-eared owl Asio otus. Ekológia (Bratislava), Vol. 34 , No. 2, p. 147-154, 2015.

During the years 2010-2012, we observed the spatial activity of long-eared owls by the radio telemetry in an agricultural land. The average home range size of tracked long-eared owls for 100 and 95\% minimum convex polygon (MCP) was 415.93 and 350 ha, respectively. Between the breeding and the non-breeding season, we did not record significant differences in the size of home ranges. Open land units (meadows and arable lands) belonged to the most abundant land units in the home ranges of tracked owls (mean for 100 and 95\% MCP was 24.6 and $24.3 \%$, respectively). Forest edges with their ecotone character also represented the abundant land unit (mean for 100 and 95\% MCP was 11.4 and 10.6\%, respectively). An amount of built-inhabited areas in home ranges (mean for 100 and $95 \%$ MCP was 8.2 and $10.1 \%$, respectively) correlated positively with their size (Spearman rank correlation: for $100 \%$ MCP: $r_{s}=0.83, p<0.05$; for 95\% MCP: $r_{s}=0.91, p<0.05$ ) that indicates long-eared owls to be avoiding built-inhabited areas as an area of the food getting. Two individuals of long-eared owl changed the winter roosts during one non-breeding season, which were at a distance of $650 \mathrm{~m}$ from each other.
\end{abstract}

Key words: land units composition, home range, long-eared owl, changing of winter-roosts.

\section{Introduction}

The creation of new anthropogenic phenomena by human beings in the landscape (Ružička, Mišovičová, 2013) may influence to all elements in land. These elements bring influences that have negative impacts to natural ecosystems, natural resources, biodiversity and landscape stability (Izakovičová, Oszlányi, 2013). Biota in agricultural landscape is the most human-affected part of exploited biota (Hreško et al., 2008). The long-eared owl is a nocturnal hunter that, prefers open land for hunting (Mikkola, 1983; Hagemeijer, Blair, 1997). Open land in Slovakia is exactly represented by land with intensive agriculture. The spatial activity of long-eared owls was studied in several works. Wijnandts (1984) brought the first information about the size of long-eared owl home ranges during the breeding and 
non-breeding season (mean 100\% minimum convex polygon $[\mathrm{MCP}]=2025 \mathrm{ha}$ ) from Netherlands by radio telemetry. Craig et al. (1988) realised the study of the spatial activity of two nesting couples in Idaho (northwest of USA) where he observed the impact of several environmental factors on the spatial activity. The accurate size of home ranges has not been mentioned. Galeotti et al. (1997) studied home ranges (mean 100\% MCP = 504.8 ha) in Po plain in Italy during the non-breeding season and proved the preferences of network habitats as green edges between fields and treelines. The lesser use of the open fields without the trees as was expected depending on their availability and the use of the forests bordering the fields regardless of the season in long-eared owls was observed in Switzerland by Henrioux (2000), mean $100 \%$ MCP was 980 ha. Lövy (2007) tracked a long-eared owl in an urban and a suburban zone in Czech Republic during the breeding season (mean 95\% MCP was $342.1 \mathrm{ha}$ ) and the home ranges of owls in the urban zone were bigger than the home ranges in the suburban zone. Tome (2011) used radio telemetry to determine the survival and dispersal of fledged long-eared owls. During the winter, long-eared owls spend the daytime at communal roosting sites. These winter roosts are often located in groups of the evergreens trees (Wijnandts, 1984). Most of the observed winter roosts are situated in the town residential areas (Noga, 2007; Škorpíková et al., 2005; Zaňát et al., 2007). Zvážal, Sviečka (2009) state potential reasons of a better micro-climate of the localities and the anti-predation strategy of owls guide their roosting behaviour. The number of owls in winter roosts varied (Wijnandts, 1984; Sharikov et al., 2014), and the number of owls in wintering areas may increase considerably compared to the breeding season (Wijnandts, 1984; Ružić et al., 2009). Wijnandts (1984) also states that some winter roosts may be abandoned in the course of winters or some owls may relocate and use other winter roosts. No other study based on radio telemetry or other works inform us about the relocations of long-eared owls between the particular winter roosts (Wijnandts, 1984; Galeotti et al., 1997; Henrioux, 2000). The aim of this study is: (i) to provide information about the home ranges size; (ii) to find out the land units composition in the home ranges; (iii) to bring information about the relocations of long-eared owls between winter roosts in the course of non-breeding season.

\section{Material and methods}

\section{Study area}

This study has been realised in the west part of Prievidza basin, Prievidza district, near the town Bojnice in the central Slovakia (Fig. 1). Long-eared owls have been captured near nests and winter roosts in two areas. The first area (winter roost A, nest Asio otus 5) consisted of the old spa park $\left(48^{\circ} 46^{\prime} \mathrm{N}, 18^{\circ} 34^{\prime} \mathrm{E} ; 315\right.$ - $250 \mathrm{~m}$ above sea level) where longeared owls have nested every year since 1992 and where they have wintered every year in the non-breeding season since 1993 (Tulis et al., 2012b). The second area was a cemetery ( $48^{\circ} 46^{\prime} 37^{\prime \prime} \mathrm{N}, 18^{\circ} 34^{\prime} 48^{\prime \prime} \mathrm{E} ; 284 \mathrm{~m}$ above sea level) where long-eared owls have wintered periodically since 2009 (winter roost B). Both areas were at a distance of $650 \mathrm{~m}$ from each other. The study area was situated in the southeast foothills of Strážovské vrchy mountains. The major part of the basin is constituted by extensive agrocenoses with several wetlands in the central part. Wetlands are consequence of anthropogenic activity (mining). These wetlands have a big impact on land and biodiversity of the whole basin (David et al., 2013).

\section{Capture and radio tagging}

Six individuals of the long-eared owl were caught using mist nets and an eagle owl bubo as a lure between 2010 and 2012 in Bojnice Spa locality. The owls were sexed according to the pattern of feathers and the colour of the mantle 
(Blasco-Zumeta, Heinze, 2010) and ringed. Radio transmitters (Biotrack Ltd., UK) weighing $4.5 \mathrm{~g}$ were attached to the two central tail feathers (Kenward, 2001). The weight of transmitters was $<5 \%$ of body weight of the smallest captured individual. All transmitters were equipped with a posture sensor. Each owl was allowed to habituate to the transmitters for at least 5 days before the collection of data started (Withey et al., 2001).
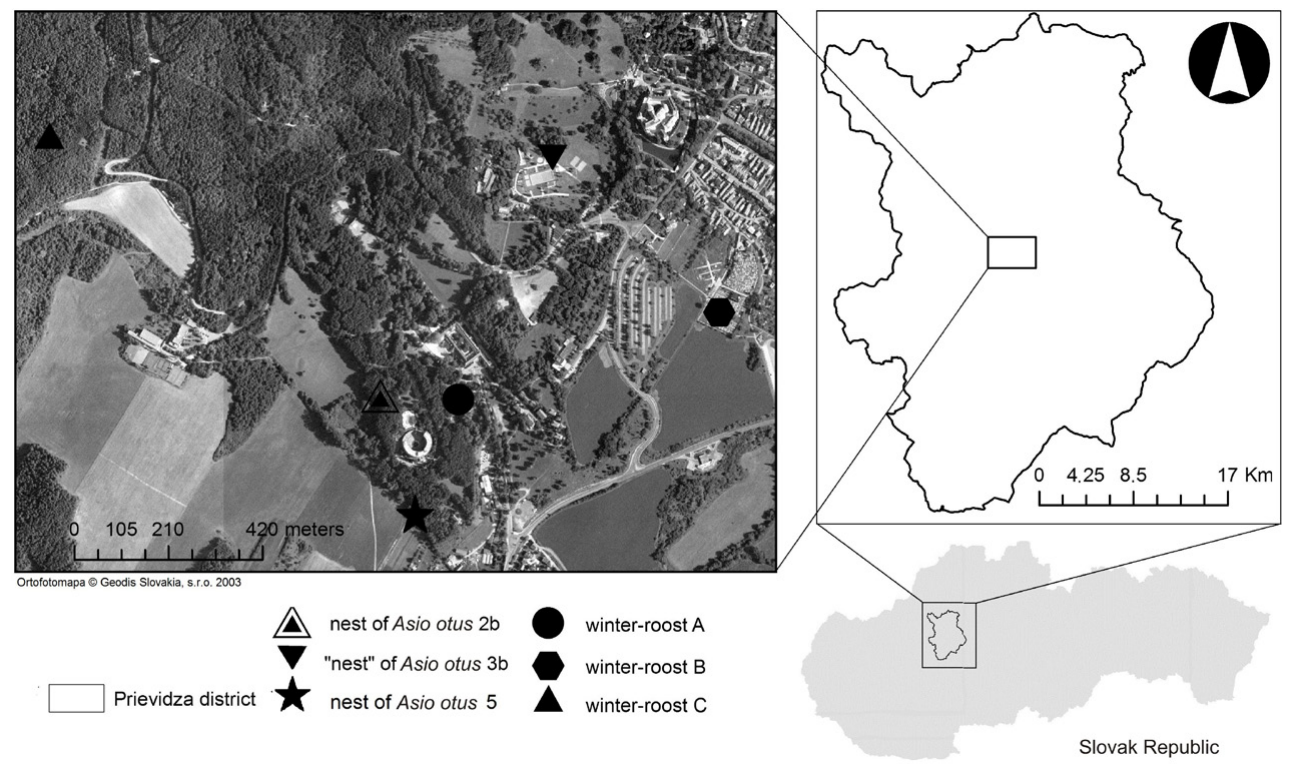

Fig. 1. Map of winter roosts and nests that were utilised by tracked long-eared owls ("nest" = nesting was not confirmed).

\section{Radio tracking}

Radio signals were received by using ICOM IC - R 10 receivers (Incom Inc., USA) and 3-element Yagi antennas. Data were recorded at $15-\mathrm{min}$ intervals. Tracking was carried out by collaboration of two persons. The direction of signal (AZIMUT) was recorded from a compass and the position of tracking person was recorded using the GPS receiver and triangulation was evaluated with Triangulation 0.1.5, Animove: Triangulation of telemetry bearings module for Quantum GIS 1.7.3 software. Individuals were tracked during the breeding season (March-July) and the non-breeding season (remainder of the year) (Wijnandts, 1984). The presence of tracked owls in the winter roost was controlled every 2 days during the non-breeding season.

\section{Home range and Land units composition}

Home ranges were generated using the home range extension for ArcView, 1996 (Rodgers, Carr, 1998) in ArcView 3.2. We used the MCP method (Hayne, 1949). Our data was designed to minimise autocorrelation (Swihart, Slade, 1985). Otis, White (1999) suggested autocorrelation is typically not relevant when individual animals are used as the sample unit. Thus, we used all fixes for the home range estimates (Forsman et al., 2005; Willley, van Riper, 2007). The number of recorded fixes of the particular individuals was always $n \geq 50$, as in Willley, van Riper (2007). We used 100 and $95 \%$ isopleths of the MCP home ranges. To compare home range size between breeding and non-breeding season, we used Mann-Withney $U$-test. Land units in every home range were evaluated by accessing on a map of present landscape structure. The map was created by digitalisation of topographic maps (Bing maps, 2012) in map scale 1:5000 using the ArcMap 10.0 software. We considered eight land units by Petrovič et al. (2009) methodology: 1. woodlands, 2. park vegetation, 3. built-inhabited area, 4. gardens, 5. linear-wood vegetation (tree lines, holding cover and windbreaks), 6. water units, 7. meadows, 8. arable land. Next, the ninth land unit was created as forest edges (with a width of $30 \mathrm{~m}$, where $15 \mathrm{~m}$ engages in the forest 
and $15 \mathrm{~m}$ to the next habitat). Differences in land units' composition between owls were tested with Friedman ANOVA test; relationship between size of home ranges and proportion of inhabited area / number of fixes was tested by Spearman rank correlation. The STATISTICA 8.0 portable software was used for all statistical analyses.

\section{Results}

\section{Home range}

Since 2010-2012, we tracked six individual long-eared owls using radio telemetry (males $=3$; females $=3$ ). Two individuals were tracked only during the breeding season, the other two were tracked during the non-breeding season and the last two were tracked during both seasons (Table 1). For these individuals, we evaluated home ranges in the breeding and the non-breeding season separately. The home range size did not correlate with the number of fixes (Spearman rank correlation: 100\% MCP: $r_{s}=-0.09, p=0.82 ; 95 \%$ MCP: $r_{s}=0.05, p$ $=0.91$ ), which indicated the data had been gained by an independent observation and that no distortion of home range size had occurred. The average home range size for 100 and 95\% MCP was 415.93 and 350 ha, respectively. The home range size of the particular owls is stated in Table 1. Although the average home range size in the non-breeding season was bigger (mean for 100 and 95\% MCP was 469.9 and 446.9 ha, respectively) than the average home range size in the breeding season (mean for 100 and 95\% MCP was 361.9 and 253.2 ha, respectively - Fig. 2), the differences were not significant (Mann-Whitney $U$ test: for $100 \%$ MCP: $U=4, \mathrm{p}=0.25$; for $95 \% \mathrm{MCP}: U=0.15, \mathrm{p}=0.15)$.

$\mathrm{T}$ a b l e 1. Home range size of tracked long-eared owls ( $\mathrm{a}$ - individual tracked in non-breeding season, $\mathrm{b}$ - same individual tracked in breeding season).

\begin{tabular}{|l|c|c|c|c|c|}
\hline Individual & Sex & Tracking period & No. of fixes & MCP 100\%(ha) & MCP 95\%(ha) \\
\hline Asio otus 1 & female & $080512-300812$ & 66 & 975.68 & 611.21 \\
\hline Asio otus $2 a^{*}$ & male & $020112-230212$ & 86 & 457.92 & 451.68 \\
\hline Asio otus $2 b^{*}$ & male & $210312-290512$ & 77 & 149.48 & 136.30 \\
\hline Asio otus $3 a^{*}$ & female & $020112-200212$ & 81 & 400.21 & 371.50 \\
\hline Asio otus $3 b^{*}$ & female & $220312-300612$ & 83 & 121.22 & 120.68 \\
\hline Asio otus 4 & male & $221111-191211$ & 88 & 263.71 & 217.95 \\
\hline Asio otus 5 & female & $060511-030811$ & 107 & 201.53 & 144.40 \\
\hline Asio otus 6 & male & $031210-240111$ & 102 & 757.72 & 746.26 \\
\hline Mean & & & 415.93 & 350.00 \\
\hline Median & & 331.96 & 294.72 \\
\hline Std. dev. & & 306.86 & 237.25 \\
\hline Std. error
\end{tabular}

\section{Land units composition}

Open land units (meadows and arable lands) were the most abundant land units in the home ranges (Fig. 3). Woodlands and forest edges also represented the abundant units. Friedman ANOVA test did not show differences in the composition of the particular land units in the 
home ranges among the individuals (for 100\% MCP: Friedman ANOVA test: $\chi^{2}=6.66, p=0.46$; for $95 \% \mathrm{MCP}$ : Friedman ANOVA test: $\chi^{2}=5.91, \mathrm{p}=$ 0.55 ). These results show that requirements of long-eared owls for land were equal and did not change depending on seasons or sex. A number of builtinhabited areas of all the tracked owls in home ranges correlated positively with their size (Spearman rank correlation: for $100 \%$ MCP: $r_{s}=0.83, p<$ 0.05 ; for 95\% MCP: $r_{s}=0.91, p<0.05$ ), which indicated long-eared owls to be avoiding built-inhabited areas.

\section{Changing of winter-roosts}

Two individuals of long-eared owls changed the winter roosts during one non-breeding season. Asio otus $2 \mathrm{a}$ and Asio otus 3 a were captured together in the winter roost B (Fig. 1) where they rested during the day together with the other six individuals. Forty seven days after the capture, both individuals had been recorded in the winter roost $\mathrm{A}$, where they stayed until the end of the wintering season together with other eight owls. The winter roosts were 650 $\mathrm{m}$ apart from each other.

\section{Discussion}

The average size of a home range $100 \%$ MCP presented in this study was smaller compared to the results of Wijnandts (1984) (mean 100\% $\mathrm{MCP}=2025$ ha; 5 tracked individuals) and Henrioux (2000) (mean $100 \% \mathrm{MCP}=980$ ha; 14 tracked individuals) that tracked owls perennially and Galeotti et al. (1997) (mean

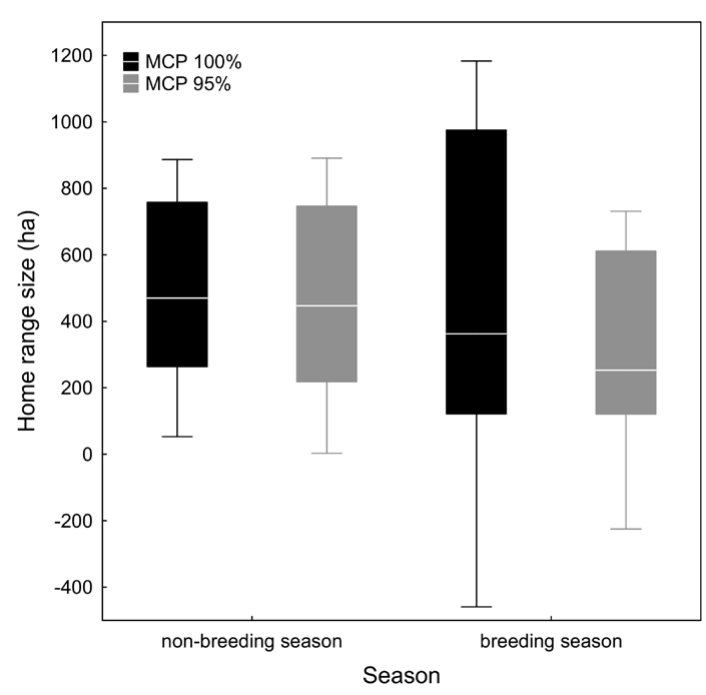

Fig. 2. Differences in long-eared owls' home range size (mean \pm min.- max.; mean $\pm 2^{\star} \mathrm{SD}$ ) between breeding and non-breeding season.

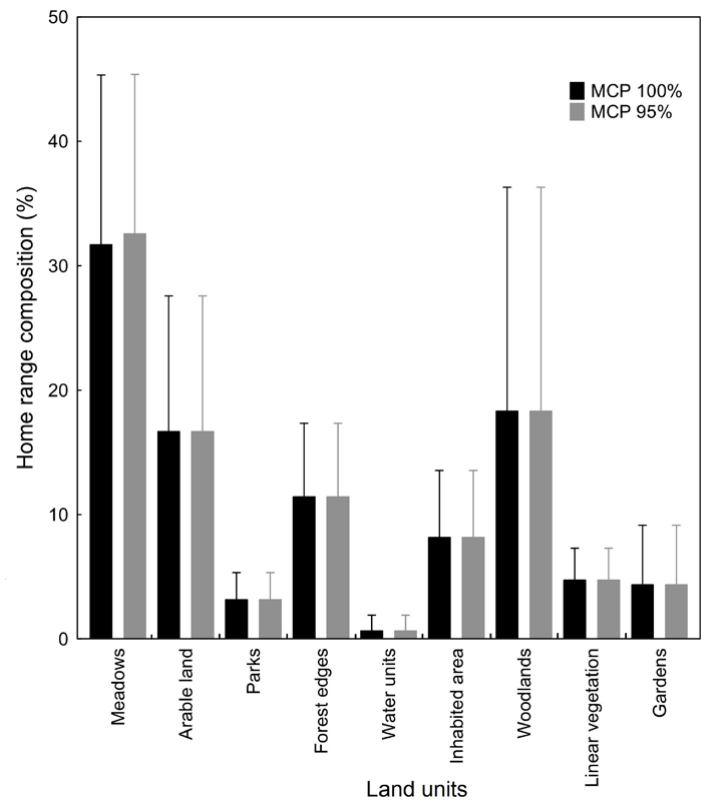

Fig. 3. Proportion of land units in home range (mean \pm SD) in 100 and 95\% MCP home ranges of long-eared owls. 
$100 \% \mathrm{MCP}=504.7$ ha; 7 tracked individuals) in the non-breeding season. Lövy (2007) (mean $95 \% \mathrm{MCP}=342.1$ ha, 9 tracked individuals) recorded a bigger average home range size in the breeding season. Marzluff et al. (1997) stated that the size of home ranges decreases with the increasing accessibility to food. Henrioux (2000) explains the increase of home ranges by the uneven distribution of the main prey - common vole - that leads owls to hunt in the new areas, but Aschwanden et al. (2005) showed that the vegetation structure is more important for selection of hunting ground than is prey abundance. Henrioux (2000) also found out the differences for the 100\% MCP in the size of home ranges depending on the season and sex. Our results are contrary to this statement but our data are limited by a smaller sample. Long-eared owl prefers hunting in an open land (Mikkola, 1983; Hagemeijer et al., 1997) that is in accordance with the high representation of open land units (meadows and arable land) in the home ranges of the tracked owls. This preference is supported by the high representation of common vole (> 84\%, Tulis et al., 2012a, b), the typical inhabitant of agrocenosis (Baláž, 2010) in the diet of long-eared owl in the study area. Woodlands were also abundant land units (mean for 100 and $95 \%$ MCP was 18.3 and $17.4 \%$, respectively), but small frequency of woodland species (<3.5\%) like yellow-necked mouse (Apodemus flavicollis) or bank vole (Clethrionomys glareolus) in diet of long-eared owl in study area showed that owls used woodlands less as hunting place. Small amount of linear vegetation was surprising, whereas this land unit was attractive mainly for songbirds as hiding and nesting place (Kalivoda et al., 2010).

The land units' composition in the home ranges has an impact on their size (Redpath, 1995). The increasing of the home ranges size caused by the increasing number of built-inhabited areas in the home ranges point out the long-eared owls avoidance of this land unit just as has been discovered by Henrioux (2000). Lövy, Riegert (2013) recorded bigger home ranges in the urban long-eared owls than in the suburban long-eared owls. These results prove that long-eared owls use the built-inhabited areas mostly for a place to hide during the day. Nesting of long-eared owls is assumed to be mainly related to a lower predator pressure in the vicinity of human dwellings in the incubation period (Sharikov et al., 2010). Owls do not find a sufficient place to get food in the built-inhabited areas that leads them to use bigger home ranges and to hunt in an open land. The evidence is given by the low representation of synanthropic mammal species in the diet of long-eared owls in the same study area during the whole year (Tulis et al., $2012 \mathrm{a}, \mathrm{b}$ ) by the fact that the main diet component - common vole gets deeper through the settlements only in the years of species gradation (Pelikán, 1986). In the forest edges, the increase of plants biomass and subsequently, the increase of herbivores abundance come about (Otto, 1994), which explains the higher representation of forest edges in the home range as a potentially suitable place to hunt. The edge habitats are very important for the land just because of their high biodiversity (Forman, 1995). Our results of the high representation of the forest edges in home ranges are in accordance with the results of Henrioux (2000). Galleotti et al. (1997), Martínez, Zubergoitia (2004), Lövy, Riegert (2013) have observed the preference of this part of the land. The number of wintering individuals changing during the winter (Noga, 2007; Pirovano et al., 2000) and their abundance culminating in December (Wijnandts, 1984) point out the fact that long-eared owls may change the particular winter roosts. It is only Wijnandts (1984) who describes the abandonment of winter roosts and the movement of the individuals between 
the winter roosts during the winter, however, without any specific facts. During our study, we have recorded several other observations, which support this theory. The tracked individual Asio otus 4 has been caught near the winter roost A (Fig. 1). During the telemetric tracking, we have localised its winter roost $1.5 \mathrm{~km}$ from the winter roost $\mathrm{A}$ in the pine wood (in the rural zone; winter roost C). Together with Asio otus 4, other six individuals of long-eared owl have been observed in this area. Twenty seven days after the marking, Asio otus 4 left the area for unspecific reasons and it was no longer recorded in the study area. The winter roost $\mathrm{C}$ has been abandoned since then. The individual Asio otus 6 remained out of reach of receivers for 12 days during the observation. It subsequently showed up in the winter roost A where it stayed for the rest of the wintering. The reason for these relocations during the winter may be a sudden change of the meteorological factors highly impacting on the diet of long-eared owls (Sharikov, Makarova, 2014), just as on the number of wintering long-eared owls itself (Pirovano et al., 2000). The other reason for the relocation to another winter roost may be a human disturbance (Noga, 2007) or other impacts and their combination.

\section{Acknowledgements}

We are grateful to Dalibor Kaplán, Karol Šotnár for their help in filed, Raptor Protection of Slovakia for material support. This study was supported by the VEGA 1/0109/13; VEGA 1/0232/12 and FCVV (Jakab).

\section{References}

ArcView (1996). The Geographic Information Systems for Everyone. Redlands: Environmental Systems Research Institute (ESRI) Inc.

Aschwanden, J., Birrer, S. \& Jenni L. (2005). Are ecological compensation areas attractive hunting sites for common kestlers (Falco tinnunculus) and long-eared owls (Asio otus)? Journal of Ornithology, 146, 279-286. DOI: 10.1007/ s10336-005-0090-9.

Baláž, I. (2010). Somatic characteristics and reproduction of common vole, Microtus arvalis (Mammalia: Rodentia) populations is Slovakia. Biologia, 65, 1064-1071. DOI: 10.2478/s11756-010-0122-7.

Blasco-Zumeta, J. \& Heinze G.M. (2010). Long-eared Owl. http://www.ibercajalav.net/img/271_LongearedOwlAotus.pdf

Craig, E.H., Craig, T.H. \& Powers L.R. (1988). Activity patterns and home-range use of nesting long-eared Owls. Wilson Bull., 100, 204-213.

David, S., Mojses, M., Petrovič, F. et al. (2013). The impact of coal mining on the landscape and biodiversity of Košských mokradí wetlands (Hornonitrianska kotlina basin) (in Slovak). Bratislava: Ústav krajinnej ekológie SAV.

Forman, R.T.T. (1995). Land Mosaics: The ecology of landscape and regions. New York: Cambridge University Press.

Forsman, E.D., Kaminski, T.J., Lewis, J.C, Maurice, K.J. \& Sovern S.G. (2005). Home range and Habitat use of Northern Spotted Owls the Olymcic Peninsula, Washington. J. Raptor Res., 39(4), 365-377.

Galeotti, P., Tavecchia, G. \& Bonetti A. (1997). Home-range and habitat use of long-eared Owls in open farmland (Po plain, northern Italy), in relation to prey availability. Journal of Wildlife Research, 2, 137-145.

Hagemeijer, W.J.M. \& Blair M.J. (Eds.) (1997). The EBCC atlas of european breeding birds - their distribution and abundance. London: $\mathrm{T}$ and $\mathrm{AD}$ Poyser.

Hayne, D.W. (1949). Calculation of size of home range. J. Mammal., 30, 1-18.

Henrioux, F. (2000). Home range and habitat use by the long-eared owl in north western Switzerland. J. Raptor Res., 34, 93-101.

Hreško, J., Bugár, G., Fehér, A., Jakabová, S., Petrovič, F., Pucherová, Z., Tuhárska, K., Vanková, V. \& Zorád L. (2008). Natural research. Nitra: Constatine the Philosopher University.

Izakovičová, Z. \& Oszlányi J. (2013). The impact of stress factors, landscape loads and human activities: Implications for sustainable development. International Journal of Environmental and Waste Management, 11, 111-128. DOI: 10.1504/IJEWM.2013.051842.

Kalivoda, H., Petrovič, F., Kalivodová, E. \& Kürthy A. (2010). Influence of the landscape structure on the butterfly (Lepi- 
doptera, Hesperioidea and Papilionoidea) and bird (Aves) taxocoenoses in Velké Leváre (SW Slovakia). Ekológia (Bratislava), 29, 337-359. DOI: 10.4149/ekol_2010_04_337.

Kenward, R.E. (2001). A manual for wildlife radio tagging. London: Academic Press.

Lövy, M. (2007). Feeding ecology of long-eared Owls (Asio otus) in urban habitat (in Czech). Diplomová práca, Jihočeská Univerzita, Česke Budějovice.

Lövy, M. \& Riegert J. (2013). Home range and land use of urban long-eared owls. Condor, 115, 551-557. DOI: 10.1525/ cond.2013.120017.

Martínez, J.A. \& Zubergoitia I. (2004). Habitat preferences for long-eared Owls Asio otus and Little Owls Athene noctua in semi-arid environments at three spatial scales. Bird Study, 51, 163-169. DOI: 10.1080/00063650409461348.

Marzluff, J.M., Kimsey, B.A., Schueck, L.S., McFadzen, M.E., Vekasy, M.S. \& Bednarz J .C. (1997). The influence of habitat, prey abundance, sex, and breeding success on the ranging behavior of Prairie Falcons. Condor, 99, 567-584.

Mikkola, H. (1983). Owls of Europe. Staffordshire: T \& A. D. Poyser.

Noga, M. (2007). Wintering and diet of long-eared Owls in Southwest Slovakia (in Slovak). Diplomová práca, Univerzita Komenského, Bratislava.

Otis, D.L. \& White G.C. (1999). Autocorrelation of location estimates and the analysis of radiotracking data. J. Wildl. Manage., 63, 1039-1044.

Otto, H. J. (1994). Forest ecology (in German). Stuttgart: Verlag E. Ulmer.

Pelikán, J. (1986). Small mammals in windbreaks and adjacent fields. Acta Scientiarium Naturalium, 20, 1-38.

Petrovič, F., Bugár, G. \& Hreško J. (2009). List of landscape units in Slovakia (in Slovak). Geo Information, 5, 112-124.

Pirovano, A., Rubolini, D. \& De Michcelis S. (2000). Winter roost occupancy and behaviour at evening departure of urban long-eared owls. Italian Journal of Zoology, 67, 63-66. DOI: 10.1080/11250000009356296.

Redpath, S .M. (1995). Inpact of habitat fragmentation on activity and hunting behaviour in the Tawny Owl, Strix aluco. Behav. Ecol., 6, 410-415. DOI: 10.1093/beheco/6.4.410.

Rodgers, A.R. \& Carr A.P. (1998). HRE: The Home Range Extension for ArcView. Ontario: Ontario Ministry of Natural Resources, Centre for Northern Forest Ecosystem Research, Thunder Bay.

Ružić, M., Radišvić, D., Tucakov, M. \& Šćiban M. (2009). Distribution and numbers of long-eared owl Asio otus communal roost in Vojvodina during the winter 2007-2008 (in Serbian). Zasvtita Prirode, 60, 295-304.

Ružička, M. \& Mišovičová R. (2013). Landscape ecological planning - Landep I (in Slovak). Nitra: UKF Nitra.

Sharikov A.V., Volkov, S.V., Ivanov, M.N. \& Basova V.B. (2010). Formation of aggregated Settlements as an Expression of Synanthropization of the long-eared owl (Asio otus L.). Russian J. Ecol., 41(1), 44-50. DOI: 10.1134/ S106741361001008X.

Sharikov, A. \& Makarova T. (2014). Weather conditions explain variation in the diet of long-eared owl at winter roost in central part of European Russia. Ornis Fennica, 91, 100-107.

Sharikov, A.V., Makarova, T.V. \& Ganova E.V. (2014). Long-term dynamics of long-eared owls Asio otus at a northern winter roost in European Russia. Ardea, 101, 171-176. DOI: 10.5253/078.101.0212.

Swihart, R.T. \& Slade N.S. (1985). Testing for independence of observations in animal movements. Ecology, 66, 1176-1184. DOI: 10.2307/1939170.

Škorpíková, V, Zaňát, J., Berka, P. \& Klejdus J. (2005). The long-eared owl (Asio otus) and its winter roosting places in South Moravia (in Czech). Crex, 25, 9-26.

Tome, D. (2011). Post-fledging survival and dynamics of dispersal in long-eared owls Asio otus. Bird Study, 58, 193-199. DOI: $10.1080 / 00063657.2011 .559531$.

Tulis, F., Slobodník, R. \& Nechalová M. (2012a). Breeding diet composition of long-eared owl in Prievidzká kotlina-basin. In Scientia Iuvenis: Books of scientific papers (pp. 197-204). Nitra: UKF.

Tulis, F., Šotnár, K. \& Obuch J. (2012b). Long-term investigation of changes in diet of wintering long-eared owls Asio otus (in Slovak). In V. Kubovcík \& S. Stašiov (Eds.), Zborník príspevkov z vedeckého kongresu “Zoológia 2012”, 18. Feriancove dni (pp. 177-178). Zvolen: TU.

Wijnandts, H. (1984). Ecological energetics of the long-eared owl (Asio otus). Ardea, 72, 1-92.

Willey, D.W. \& van Riper C.H. (2007). Home range characteristics of Mexican Spotted Owls in the Canyonlands of Utah. J. Raptor Res., 41, 10-15. DOI: 10.3356/0892-1016(2007)41[10:HRCOMS]2.0.CO;2.

Withey, J.C., Bloxton, T.D. \& Marzluff J.M. (2001). Effects of tagging and location error in wildlife radiotelemetry studies. San Diego: Academic Press.

Zaňát, J., Škorpíková, V. \& Berka P. (2007). The long-eared owl (Asio otus) and its winter roosting places in South Moravia II (in Czech). Crex, 27, 8-34.

Zvářal, K. \& Sviečka J. (2009). Is the long-eared owl (Asio otus) sedentary, nomadic or migratory (in Slovak). Tichodroma, 21, 79-87. 